\title{
How Digital Platforms Enhance Urban Resilience
}

\author{
Dong Qiu ${ }^{1}\left(\mathbb{D}\right.$, Binglin Lv $^{1}(\mathbb{D})$ and Calvin M. L. Chan ${ }^{2, *(\mathbb{D})}$ \\ 1 School of Management, Fujian University of Technology, Fuzhou 350118, China; qiudong@fjut.edu.cn (D.Q.); \\ lvbinglin@163.com (B.L.) \\ 2 School of Business, Singapore University of Social Sciences, Singapore 599494, Singapore \\ * Correspondence: calvinchanml@suss.edu.sg; Tel.: +65-6248-4446
}

check for updates

Citation: Qiu, D.; Lv, B.; Chan, C.M.L. How Digital Platforms Enhance Urban Resilience. Sustainability 2022, 14, 1285. https://doi.org/10.3390/ su14031285

Academic Editors: J. Ramon Gil-Garcia, Mila Gasco-Hernandez and Tzuhao Chen

Received: 24 December 2021

Accepted: 19 January 2022

Published: 24 January 2022

Publisher's Note: MDPI stays neutral with regard to jurisdictional claims in published maps and institutional affiliations.

Copyright: (C) 2022 by the authors. Licensee MDPI, Basel, Switzerland. This article is an open access article distributed under the terms and conditions of the Creative Commons Attribution (CC BY) license (https:// creativecommons.org/licenses/by/ $4.0 /)$.

\begin{abstract}
Throughout human history, natural and man-made disasters have devastated cities in unpredictable ways. Cities must therefore respond faster and better to minimize the risks posed by disasters. Nowadays, with the rapid development of communication technology, digital platforms are increasingly becoming an indispensable part of people's lives; hence, they could become a new force for urban resilience. However, there are few studies on how digital platforms enhance urban resilience, so this paper attempts to use the method of CiteSpace (V.5.8.R3, 64 bit) scientometrics analysis and literature analysis to study the dimensions and trends of urban resilience, the role of digital platforms in the dimensions of urban resilience, especially focusing on how digital platforms impact on urban resilience during COVID-19. The results showed that there is considerable literature on natural disasters and infrastructure, but few papers discuss urban governance, knowledge systems, and social media. Furthermore, it is also found that digital platforms contributed to the enhancement of urban resilience in China and Singapore during COVID-19. These suggests that enhancing urban resilience through digital platforms can be a viable approach.
\end{abstract}

Keywords: digital platforms; urban resilience; sustainable city; framework; case study; COVID-19

\section{Introduction}

Throughout human history, cities and societies have regularly been exposed to various forms of crisis. Even as humanity enters into the digital age of smart cities and Industry 4.0, humanity continues to be exposed to the onslaught of various crises ranging from dramatic shocks such as floods and earthquakes to long-term stresses caused by climate change and social dynamics. Urban resilience enables individuals as well as cities to overcome disruption, recover from disasters, and continuously develop a better future. Cities must therefore be more resilient and prepared to deal with shocks and stresses to reduce the impact of disasters on people and cities. However, compared to other kinds of resilience, such as economic resilience, the concept of urban resilience remains ill-defined [1].

How to use markets, enterprises, social organizations, and innovation to enhance urban resilience is a research problem of theoretical and practical significance. With the ubiquity of information and communication technology and the democratization of innovation, digital platforms have emerged as a new paradigm of economic and social development. Enhancing urban resilience through digital platforms is achievable and extremely important. Therefore, how digital platforms effectively enhance urban resilience is a topic worth studying.

This study aims to answer the following questions. First, what are the dimensions of urban resilience? Second, what is the role of digital platforms in the dimensions of urban resilience? Finally, how do digital platforms affect urban resilience, especially during COVID-19? The research framework of this study is shown in Figure 1. 


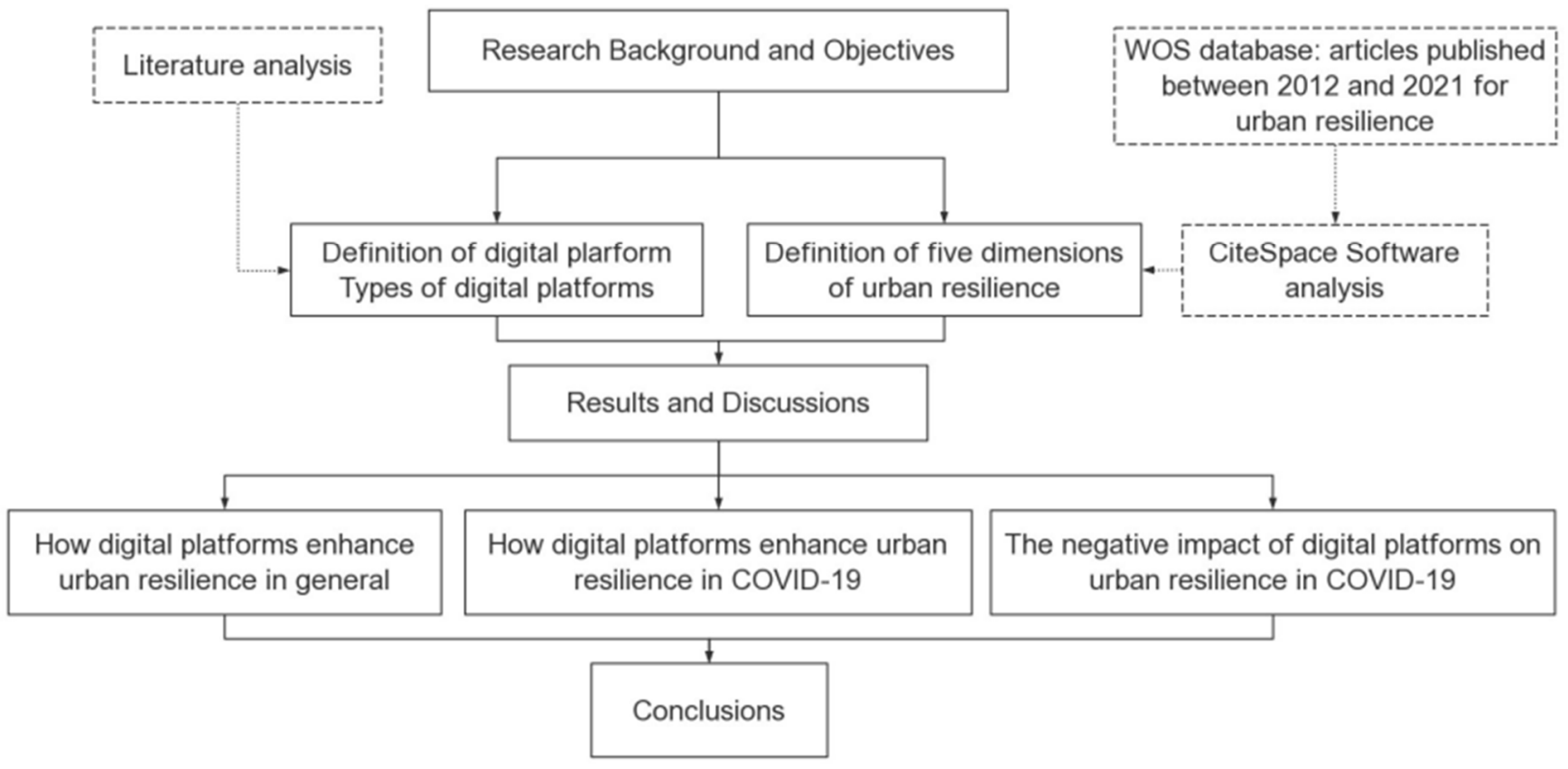

Figure 1. The research roadmap.

\subsection{Urban Resilience}

The English word "resilience" stems from the Latin "resilio", which means "bounce". The term passed into Middle French (résiler), which means "to retract" or "to cancel", and subsequently evolved into modern English "resile", which is still used today. The concept of resilience has been applied to different disciplines over time. With the Industrial Revolution in the mid-19th century, the term resilience became widely used in mechanics to describe the ability of metals to recover after being deformed by external forces. From the 1950s to the 1980s, "resilience" was widely used in western psychological studies to describe the ability to recover from mental trauma [2]. Holling, the American-Canadian ecologist, first applied the concept of resilience to the field of Systems Ecology, proposing that ecological resilience refers to "the ability of system maintenance and adaptation". Since the 1990s, the study of resilience gradually expanded from natural ecology to human ecology [3]. Resilience has since become an indispensable subject in the study of human ecology. It has been applied to area of urban studies, laying the theoretical foundation for the resilience city theory.

Although urban resilience has been receiving attention from the academic community for some time now, the concept of urban resilience and the associated research is observed to be lacking a unifying focus. Scholars in different disciplines study urban resilience from different perspectives, including disciplines such as the natural sciences and ecological studies, sociology, psychology, and even philosophy. The concept of urban resilience across different studies may refer to completely different things.

Through an in-depth content analysis of highly cited articles, the following three definitions of urban resilience is found to be most representative.

Firstly, urban resilience refers to the ability of an urban system and all its constituent socio-ecological and socio-technical networks across temporal and spatial scales in maintaining or rapidly returning to desired functions in the face of disturbance, or adapting to change, and quickly transforming systems that limit current or future adaptive capacity [4].

Secondly, urban resilience is defined as the ability of individuals, communities, institutions, businesses, and systems within a city to survive, adapt, and grow no matter what kinds of chronic stresses and acute shocks they experience $[5,6]$. 
Finally, urban resilience is defined as the capacity of a city and its urban systems (social, economic, natural, human, technical, physical) to absorb damage, to reduce impacts (changes, tensions, destruction, or uncertainty) from disturbances (shock, natural disaster, changing weather, disasters, crises or disruptive events), and to adapt to changes in the systems that limit current or future adaptive capacity [7].

While the above three definitions offer different description of urban resilience, what is unanimous is that "Urban resilience is a concept to describe the ability of either individuals or groups within cities to cohesively organize in responding affirmatively to crises and disruptions."

Meerow et al. [4] posited an urban resilience conceptual framework, consisting of (1) governance networks, (2) networked material and energy flows, (3) urban infrastructure and form, and (4) socioeconomic dynamics. Governance networks refer to the various actors and institutions whose decisions shape urban systems, including states, nongovernmental organizations, and businesses. Network materials and energy flows refer to various materials, such as water, food, energy, and waste flows, generated or consumed in or by urban systems, which are often referred to as "urban metabolism". Urban infrastructure and forms include the built environment, such as buildings, transportation networks, energy, and hydropower networks, as well as urban parks and green spaces. Finally, socioeconomic dynamics refers to the dynamics of justice and equity, demographics, and monetary capital that shape the above elements as well as the livelihoods and capacities of the urban citizens.

Spaans et al. [6] proposed an urban resilience framework for Rotterdam based on the resilience indicator framework developed by ARUP [5], including (1) health and wellbeing, (2) economy and society, (3) infrastructure and environment, and (4) leadership and strategy.

Ribeiro et al. [7] identified urban resilience to consist of (1) physical, (2) natural, (3) economic, (4) institutional, and (5) social aspects. "Physical" resilience includes the development of resilience in infrastructures, "Natural" resilience includes ecological and environmental resilience, "Economic" resilience includes the development of societies and economies, "Institutional" resilience includes governance and mitigation policies, and "Social" resilience includes resilience of communities and people in general. Torabi et al. [8], however, argue that a "Political" dimension should be added as it is the prerequisite for the realization of the above five dimensions.

As evidenced from the above review, urban resilience is a broad, complex, and dynamically evolving concept, with different scholars holding different perspectives and definitions. Notwithstanding, there is considerable overlap across the different perspectives and definitions.

Table 1 attempts to construct an integrative framework through the categorization of factors. In all factor, five dimensions are presented, namely: (1) Natural, which includes the ecological and environmental. (2) Infrastructures, such as education, medical care, transportation, material supply, etc., are usually a combination of physical and social infrastructure, which provide the basic guarantee for the urban resilience system. (3) Institutions and management capabilities are considered to be an important force to maintain the normal operation of the social system and promote recovery under shocks. (4) Economic includes the development of societies and economies. (5) Social (e.g., social networks) is the most widely mentioned element, which can be regarded as the most important feature of urban resilience, distinguishing urban resilience from individual resilience, physical resilience, and ecological resilience.

While the concept of urban resilience is not absolute and static, the process of abstracting and operationalizing these dimensions of urban resilience is important for managers to support specific areas of urban resilience [9]. 
Table 1. Dimensions of urban resilience (See Appendix A for detailed data).

\begin{tabular}{cl}
\hline Dimensions & \multicolumn{1}{c}{ Subdimensions } \\
\hline Natural & Ecosystems, Environment, Biodiversity, Hydrogeololgy. \\
\hline \multirow{2}{*}{ Infrastructure } & $\begin{array}{l}\text { Physical Infrastructure, Social Infrastructural, Land Use and Structural Design, Physical Capital, } \\
\text { Transportation network, Commercial and manufacturing establishments, Water and Energy supply } \\
\text { systems, Flexibility of grid. }\end{array}$ \\
\hline \multirow{2}{*}{ Institutional } & $\begin{array}{l}\text { Governance, Organized Governmental Services, Resource Management, Warning and Evacuation, } \\
\text { Emergency Response, Disaster Recovery, Management Capacity. }\end{array}$ \\
\hline \multirow{2}{*}{ Economic } & $\begin{array}{l}\text { Society and Economy, Employment, Financial stability and flexibility, Job diversity of residents, } \\
\text { Sousing capital, E-commerce. }\end{array}$ \\
\hline \multirow{2}{*}{ Social } & $\begin{array}{l}\text { Human Capital, Lifestyle and Community Competence, Community Capital, Social and Cultural Capital, } \\
\text { Population and Demographics, Social values-cohesion, Social Networks, Learning Capacity, Innovation, } \\
\text { Education;Cultural diversity, Faith-based organizations. }\end{array}$ \\
\hline
\end{tabular}

\subsection{Digital Platforms}

Digital platforms can be understood as a socio-technical assemblage encompassing the technical elements of software and hardware, and associated organizational processes, standards, and dynamics [10]. To be successful, digital platforms need to attract a diversity of active actors that assume different roles [11]. The interaction and/or interdependence among actors is another key characteristic of a platform ecosystem [12,13]. The evolutionary dynamics of digital platforms are influenced by the co-evolution of the architecture, governance, and environment of the platform [14]. Such an ecosystem not only enables the co-existence of a diversity of actors but also balances the interests of these diverse actors [11]. Over time, the many independent actors form an ecosystem of heterogeneous complementors around a stable digital platform's core [15]. In a functioning ecosystem, the focus will revolve around producing generative activities associated with the success of the digital platforms [16]. This requires a delicate balance of governance and control by the digital platform owner and autonomy and participation of both producing as well as contributing actors [14], which Tilson et al. [10] proposed to be the paradox of change and control. The paradox of change means that digital platforms need to be stable to attract further enrolment, and flexible enough to support seemingly limitless growth. The paradox of control puts forward the opposing logic of the centralized and distributed control mechanism of digital platforms [17]. A similar mechanism has also been proposed by Wareham et al. [15] to manage the tensions that characterize digital platforms.

There exist different types of digital platforms, such as social media platforms (e.g., Facebook, Instagram, YouTube, TikTok), smartphone operating systems platforms (e.g., IOS, Android), digital payment platforms (e.g., AliPay, WeChatPay, ApplePay), and peer-to-peer digital platforms (e.g., Airbnb, Uber, Grab). According to their major functions and advantages, these digital platforms can be sorted into three main categories of community-based digital platforms, innovation-based digital platforms, and trade-based digital platforms. These different categories may evolve, transform and even fuse over time. For example, community-based digital platforms may evolve and extend to also become a trade-based digital platform where community members of the platform take to trading goods and services on the platform [18].

Moreover, functioning digital platforms leverage the greater ecosystem of producing actors with the right skills and appreciation of the needs and preferences of the consuming actors to creatively enhance the features and appeal of the digital platforms $[11,16]$. This, in turn, enriches and sustains the interest of consuming actors towards the platform [14]. Hence, by tapping on the ecosystem of producing actors, the digital platforms can be even more innovative [19] than if they had relied on an internal resource [20]. 


\section{Materials and Methods}

Given the diversity of research fields involved in studying urban resilience, it is difficult to anchor on a single field or a fixed set of journals in carrying out a systematic literature review. We thus conducted a preliminary search through the Database of Web of Science $^{\mathrm{TM}}$ Core Collection. After excluding non-academic papers such as book reviews, conferences, and newspapers, the Web of Science has 1080 records between 2012 and 2021 based on a topic search of the rules "TS = (" resilient city "or" urban resilience "or" city resilience "or" resilient urban ")' in titles, abstracts or indexing terms. In this article, unless stated otherwise, the relevant literature is reviewed as of November 2021.

To further analyze related research topics, 1080 previous articles were imported into CiteSpace (V.5.8.R3, 64 bit) after removing duplicates [21]. CiteSpace is an open-source Java application [22]. Applying CiteSpace, the 1080 articles were checked for keyword cooccurrence analysis and clusters. Co-occurrence analysis is a bliometric method to extract the high and low distribution of keywords frequency that can express the core content of the literature information. Through literature co-occurrence analysis, the research hotspots of urban resilience were revealed, and the development track of this research field was grasped [4].

The following parameters were set before running CiteSpace:

(1) In the time period segmentation, set the analysis time from 2012 to 2021, and set the time partition length to " 1 ";

(2) Text processing select "Author Keywords";

(3) Select the "Keywords" as the network node type;

(4) "Coise" algorithm was used to calculate the strength of network associated nodes, and "Within Slices" was selected as the calculation range;

(5) Selection Criteria select "Top $\mathrm{N}=50$ ";

(6) Finally, the "Pathfinder, Pruning the merged network and Pruning the merged network".

After running the CiteSpace, a 158-node and 261-link co-occurrence network and 10 major clusters (The red label of \#0-\#9 in Figure 2) were obtained. The label of the clusters is generated automatically by the CiteSpace Log-Likelihood Ratio (LLR) test method, which is considered to be the most popular and best cluster label selection method [23]. The modularity value is 0.5995 and the silhouette value is 0.8774 ; both of them are larger than 0.5, which suggests that the network is reliable. The color of the cluster corresponds to that of each time slice and the cluster labels represent the mainstream direction of research in that year. Each node in the cluster represents a keyword, and the larger the node, the more frequently the keyword appears. Similarly, the color of the node ring corresponds to the year in which the keyword appears, and the thicker the node ring is, the more frequently it appears in that year. The outer circle of a node with high centricity will appear in purple color.

As shown in Figure 2, it is clear that the earlier literature on urban resilience mainly focused on (i) urban resilience in tackling natural disasters and climate change, and (ii) urban resilience in urban infrastructure planning and construction. However, in clusters 2\# and 5\#, we found that new research directions such as urban governance (the pentagram and the blue label in Figure 2) and social media started to emerge in the study of urban resilience. This suggests that more scholars were researching on urban governance and social media in the development of urban resilience in the most recent two years. 


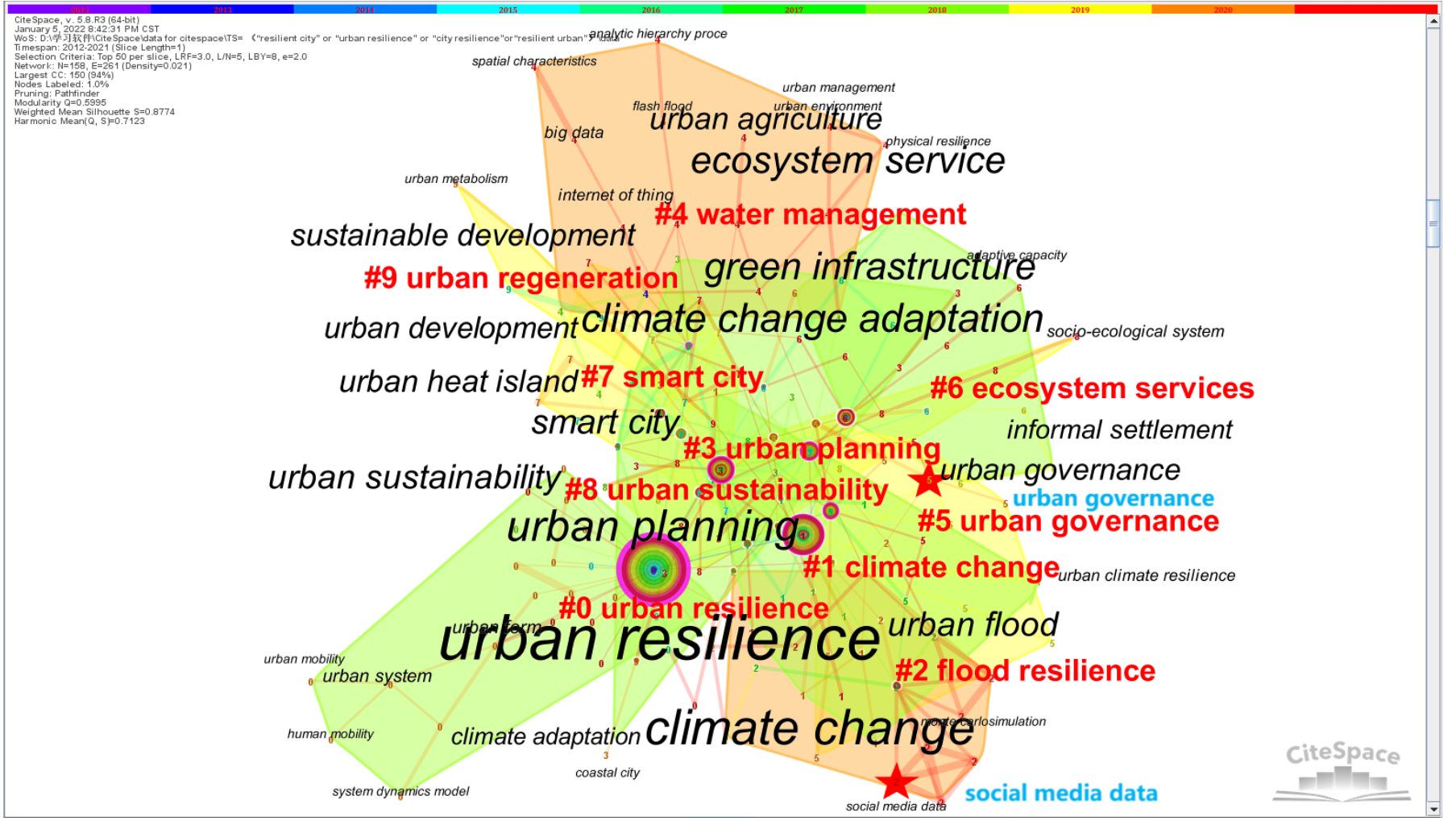

Figure 2. Major research clusters in urban resilience.

\section{Results and Discussion}

\subsection{Urban Resilience and Digital Platforms}

Urban resilience and digital platforms are two emerging research topics, and there are not many studies that combine these two. However, existing literature suggests that digital platforms could support the development of urban resilience. Thus, based upon the five-dimension framework presented earlier, this section considers how digital platforms enhance urban resilience through a review of relevant literature, which is summarized in Table 2.

Table 2. How digital platforms enhance urban resilience.

\begin{tabular}{|c|c|c|}
\hline Dimensions & Category & Approach of Enhancement \\
\hline \multirow{2}{*}{ Natural } & Mobile platform & Biodiversity monitoring, reduce pesticide inputs to improve environmental benefits \\
\hline & Multiple digital platforms & Improve urban forest performance \\
\hline \multirow{2}{*}{ Infrastructure } & Social media platform & Reconstructive activities to physical facilities, educational infrastructure \\
\hline & Multiple digital platforms & Digital health infrastructure \\
\hline \multirow[t]{2}{*}{ Institutional } & Social media platform & $\begin{array}{l}\text { Initiate public activities, initiate emergent citizen groups, increase consultation } \\
\text { rights }\end{array}$ \\
\hline & Multiple digital platforms & Promote public participation in urban governance. \\
\hline \multirow{2}{*}{ Economic } & Multiple digital platforms & $\begin{array}{l}\text { Tourism product innovation and sales channel reform, } \\
\text { Online shopping promotes economic development during the pandemic }\end{array}$ \\
\hline & Mobile platform & Increase agricultural production and incomes \\
\hline \multirow[t]{2}{*}{ Social } & Social media platform & $\begin{array}{l}\text { Digital identity, provide social support, share ideas, information sharing and } \\
\text { communication, multicultural communication and sharing of common beliefs and } \\
\text { values }\end{array}$ \\
\hline & Multiple digital platforms & Revitalize local traditional techniques. \\
\hline
\end{tabular}


Nitoslawski et al. [24] observed that digital platforms could be used to improve urban forest performance and enhance the delivery of benefits provided by urban green infrastructure in the Netherlands. For instance, "TreeMania" sensors collect soil moisture data in real-time and send watering information to tree managers or directly send it to nearby residents to promote civic participation in the maintenance of the city's trees.

Bhaskara et al. [25] introduced the case of the real-time interaction platform "eKisaan" in Karnataka, India. This platform aims to provide farmers with local agricultural information and the latest agricultural policies and technologies to reduce farmers' agricultural inputs, increase yields and incomes, and improve the local ecological environment by reducing fertilizer and pesticide inputs. Dwivedi [26] presented another case, where wildlife experts trained local volunteers through the use of Zoom, Google Meet, live sessions on Facebook, and a specially developed mobile app platform called "Ganga Data Collector" to train volunteers in sharing photos and videos, as well as other information about the biodiversity during COVID-19 so that research can continue even in the face of social distancing measures in India.

Farinosi et al. [27] observed that the use of internet technologies, especially social media platforms, increased among the local citizens in the aftermath of an earthquake in L'Aquila, a small city in central Italy, on 6 April 2009. Through the social media platforms, citizens were able to reestablish communication among the community. They subsequently progressed to launching various public activities through the social media platform and finally reconstructed online space for socialization in place of the physical space which had been damaged by the quake.

Effendi [28] also demonstrated how social media platforms could be used as a multicultural educational infrastructure. Through such multicultural communication and the sharing of common beliefs and values on the digital social media platform, cooperative relationships among different social groups were established, eliminating tensions and conflicts among these social groups, and improving the urban resilience among them.

Udwan et al. [29] also presented a case study on Syrian refugees living in the Netherlands, revealing how social media platforms provided social support (social networks and culture) to these refugees and catered to their psycho-social wellbeing. Moreover, digital health platforms offered these refugees to seek healthcare information and even online medical consultation services. As the social media platform also enabled the refugees to share their political views and religious thoughts, the platform also served to forge a shared digital identity through the sharing, which relates to the development of human capital and social capital as factors of urban resilience.

Reuter et al. [30] also posited that social media could foster urban resilience, as many European residents already used social media to share and find information in emergency situations. As more and more citizens took to using social media, there is also a corresponding growth in expectation for emergency information and services to be delivered to citizens via social media. Such expectation also led to the emergence of citizen-initiated groups on social media to drive digital volunteerism. Thus, digital platforms not only could strengthen the sharing and communication of information and knowledge in dealing with an emergency, but they also promote active citizenry participation and give rise to urban resilience.

Young [31] conducted a case study on the Inuit in the Canadian Arctic use of digital platforms to build local food economies, revitalize indigenous hunting techniques, and promote increased consulting rights for regional development projects, which enhance urban resilience in terms of skills and innovation, as well as engaged governance.

Zheng et al. [32] also examined digital platforms in Shanghai, China, such as DiDi and Airbnb, to reveal how these platforms offer significant advantages over traditional modes in matching supply and demand of tourism resources, mobilizing a large amount of idle resources for Shanghai's tourism industry, revitalizing the local tourism resource stock and greatly promoting the development of local tourism. 
As is observable from Table 2, existing studies on how digital platforms support the development of urban resilience have primarily focused on social media digital platforms.

\subsection{How Digital Platforms Enhance Urban Resilience in COVID-19}

With little contestation, COVID-19 is one of the most disruptive events in recent history, challenging the urban resilience of many communities, societies, and countries. The widespread and extended period of shutdown and lockdown has disrupted not only economic activities but also social and community activities and has threatened the functioning of the very fabric of societies. Nevertheless, even as corporeal interaction became prohibited, many have taken to sustaining some semblance of social and community functioning online, especially through digital platforms. Digital platforms are thus posited to be a powerful instrument to mitigate the impact of the pandemic. These have been observed to enhance urban resilience by facilitating information collection, transmission and analysis, pandemic monitoring, community management, and the delivery of critical services.

This section thus offers a narrative of how digital platforms engendered urban resilience, with examples drawn from Singapore and China during the COVID-19 pandemic. Both countries were chosen because they were the first countries to encounter the COVID19 virus and both have leveraged their advanced level of digitalization and well-developed digital platforms to effectively mitigate the impact of the COVID-19 pandemic [33] (see Table 3).

Table 3. Leveraging on digital platforms to enhance urban resilience in COVID-19.

\begin{tabular}{|c|c|c|c|}
\hline \multirow{2}{*}{ Dimensions } & \multirow{2}{*}{ Common Practices } & \multicolumn{2}{|c|}{ Features } \\
\hline & & Singapore & China \\
\hline Natural & Not found & Not found & Not found \\
\hline Infrastructure & $\begin{array}{l}\text { Online work, online education, smart logistics; } \\
\text { Temperature checks and identity registration } \\
\text { system in public places } \\
\text { Tracking mobile phone software applications } \\
\text { Ensure strict enforcement of isolation through } \\
\text { digital means }\end{array}$ & $\begin{array}{l}\text { Elderly activity center holds online } \\
\text { activities. }\end{array}$ & $\begin{array}{l}\text { Rapid construction of hospitals through } \\
\text { collaborative work on digital platforms } \\
\text { Online diagnosis and drug delivery. }\end{array}$ \\
\hline Institutional & $\begin{array}{l}\text { Different departments strengthen information } \\
\text { sharing and coordinated decision-making } \\
\text { through digital platforms; } \\
\text { Further improvement of e-government. }\end{array}$ & $\begin{array}{l}\text { The public participates in public } \\
\text { decision making through digital media. }\end{array}$ & $\begin{array}{l}\text { Adopt "digital government" platform to } \\
\text { implement online government affairs } \\
\text { examination and approval system. }\end{array}$ \\
\hline Economic & $\begin{array}{l}\text { Leveraging digital platforms to boost economic } \\
\text { development during the pandemic. }\end{array}$ & $\begin{array}{l}\text { Use Facebook to promote hawker } \\
\text { economy. }\end{array}$ & $\begin{array}{l}\text { Use various digital platforms to ensure the } \\
\text { supply of daily necessities. }\end{array}$ \\
\hline \multirow{3}{*}{ Social } & $\begin{array}{l}\text { Mobilize and train first responders and medical } \\
\text { professionals to respond to the pandemic; } \\
\text { Encourage the public and communities to } \\
\text { participate in pandemic prevention; } \\
\text { Advocate special care for the elderly and other } \\
\text { vulnerable people. }\end{array}$ & $\begin{array}{l}\text { Provide training for the elderly in the } \\
\text { use of digital devices; } \\
\text { Use digital platforms to mobilize } \\
\text { volunteers to help vulnerable people. }\end{array}$ & Not found. \\
\hline & $\begin{array}{l}\text { Publish pandemic information and prevention } \\
\text { policies; } \\
\text { Publish policies for reopening and work resuming; } \\
\text { Report personal information and whereabouts. }\end{array}$ & $\begin{array}{l}\text { Actively prevent the spread of fake } \\
\text { news; } \\
\text { Use easy-to-accept information formats } \\
\text { such as cartoons and short videos. }\end{array}$ & $\begin{array}{l}\text { Population migration big data platform and } \\
\text { digital map of pandemic } \\
\text { Use online payment platforms to quickly } \\
\text { promote a 'health code' which collects and } \\
\text { analyzes personal health information. }\end{array}$ \\
\hline & $\begin{array}{l}\text { Increase community network interaction through } \\
\text { digital platforms; } \\
\text { The public uses social media to cheer for medical } \\
\text { staff and those involved in the fight against the } \\
\text { pandemic. }\end{array}$ & $\begin{array}{l}\text { Provide online communication for the } \\
\text { elderly; } \\
\text { Provide electronic pass tokens for the } \\
\text { elderly; } \\
\text { Organize online events, such as virtual } \\
\text { concerts and festival celebrations, to } \\
\text { boost morale. }\end{array}$ & Not found. \\
\hline
\end{tabular}

\subsubsection{Infrastructure}

During the lockdown, online work and online education became the new normal. Various digital platforms' infrastructures were utilized to enable such a new normal. Some of the more prominent infrastructures include video conferencing platforms (e.g., Zoom), online payment platforms (e.g., Paypal), and also various smart logistics infrastructures that enabled the fulfillment of e-commerce orders. 
In Singapore, people who were visiting places such as shopping malls, restaurants, and supermarkets were required to use a SafeEntry smart phone app to scan a QR code to checkin and out [34]. Another TraceTogether smartphone app used Bluetooth sensors to detect other smartphones that were also using the TraceTogether app in the vicinity [35]. For senior citizens or pockets of society who did not use smartphones, the government distributed TraceTogether Tokens, which were Bluetooh-based sensor tags [36]. These technologies enabled an effective tracing of individual movement for contact tracing to prevent the spread of the virus.

In Singapore, senior activity centers across the island-state, which cater to seniors' mental, social as well as physiological wellbeing, were closed as the COVID-19 virus was most lethal among older people [37]. Although the center was closed, events that used to be held at the senior centers switched to be live-casted on digital platforms.

In China, emergency hospitals were built in a very short time, enabled through collaborative design, procurement, construction, and project management on digital platforms, as well as the application of Building Information Modeling technology [38].

\subsubsection{Institutional}

Through digital platforms, different government agencies such as healthcare, public security, science, and technology, were able to share pandemic information and implement coordinated decision-making and action for an effective response to the pandemic.

In Singapore, it was observed that social media platforms facilitated public participation in decision-making during the pandemic. For example, a large-scale parade had always been a main focal point in Singapore's National Day celebration. However, during the COVID-19 pandemic, many people in the communities advocated for the parade to be canceled, while others felt that it should be held to boost morale and bring Singaporeans together in solidarity during such difficult times. Taking into consideration the online chat and feedback in both traditional and social media platforms, it was subsequently decided that the parade should go ahead, albeit in a distributed manner and on a smaller scale [39].

In China, through the national integrated online government service platform, local governments continued to function in full service, promoting online government services with "No meeting" and "No contact". In of the making pandemic prevention arrangements and the approving of production resumption, the Chinese government introduced innovative online applications such as "no in-person examination and approval", and "contactless service". This not only enabled the normal operation of social and economic activities, but also avoided the gathering of crowds to prevent the pandemic from spreading further [40].

\subsubsection{Economy}

To counter the impact of COVID-19 on economic development, China and Singapore took to digital platforms to boost economic activities. In Singapore, the Infocomm Media Development Authority teamed up with vendors at a fresh produce market to sell fresh produce on Facebook [41]. This innovative collaboration not only helped the vendors to develop new sales models, but also played a vital role in ensuring the daily rhythm of life were maintained to some degree during the pandemic. Furthermore, some hawker stall owners in Singapore also came together on their own accord to create a Facebook public group called "The Hawker Alliance" so that diners could order food through the hawker stall owners' Facebook pages.

In China, the manufacturing sector pooled resources through digital platforms to accelerate the resumption of production. For example, Haier Group established a resource sharing aggregation platform to provide pandemic information management and analysis services [42]. Digital platforms such as Industrial Internet Platform provide support for material docking, remote collaborative design, and remote operation and maintenance after the resumption of work and production by taking advantage of online collaboration, remote collaboration and remote services. To cope with the dilemma of unsalable agricultural products, Brick launched an agricultural big data platform to improve the 
risk-resistance ability of the traditional agricultural supply chain and to increase circulation efficiency by linking various elements in the agricultural supply chain system. E-commerce platforms such as Taobao, JD.com, and Pingduoduo also launched channels to help farmers by opening up new online channels to sell their agricultural products. These digital platforms addressed the issue of production and marketing of agricultural produce during the pandemic. Furthermore, in face of unstable labor demand, dozens of enterprises in different industries developed an employment-sharing scheme and platforms to enable the sharing of manpower. This provided some assurance of continuity in employment during the pandemic.

\subsubsection{Social}

During the COVID-19 pandemic, many governments around the world mobilized and trained first responders, medical professionals, and volunteers to respond to the pandemic. In some instances, members of the public and communities were also recruited as volunteers to join in various initiatives to prevent the spread of the virus or to support the elderly or other vulnerable groups in society.

In Singapore, some community-based digital platforms used smartphone applications, artificial intelligence, and big data technology to facilitate the matching of individuals seeking various kinds of help with relevant volunteers [43]. In order to help the elderly cope with the pandemic and maintain some normalcy of life, Singapore's government and social service agencies partnered to provide digital training for the elderly, covering digital skills such as making video calls, connecting to WiFi, and basic cybersecurity tips. These training progressed to also teach the elderly to access online municipal services, making online payment and online shopping [44].

Pandemic related information and anti-pandemic policies were also often disseminated to residents and companies through digital platforms such as Facebook, WhatsApp, and Twitter. Individuals and companies also took to these digital platforms to pick up relevant information. However, there were also cases of fake news spreading through digital platforms during the pandemic. The spread of such misinformation often caused chaos, psychological distress, and instances hysteria of anti-social behavior $[45,46]$.

Singaporean government relied not only on traditional media but also on social media to eliminate such disinformation by providing reliable sources of information related to the pandemics on popular social media platforms (e.g., WhatsApp and Telegram). Those who are interested could subscribe to these social media platforms, and receive official information through these platforms, thus preventing the spread of fake news [47]. In addition, Singapore also used a large number of short videos and cartoons to promote pandemic prevention information. Its official promotional animations were so popular that even the World Health Organization translated it to multiple languages for international dissemination [48].

In China, due to the popularity of electronic payment platforms such as Alipay and WeChatPay, plug-in 'health code' apps were built into these electronic payment platforms, and it was possible to rapidly disseminate the use of these plug-in apps which recorded personal travel and health assessment history [49]. Notwithstanding, as the elderly remained among the least technologically savvy individuals in many societies, there were still pockets in societies that may be digitally excluded. A case in point is that of an elderly person who was turned away from taking the subway because he could not use the plug-in 'health code' app [50].

Furthermore, the Baidu Maps (similar to Google Maps) platform launched a series of functions that captured and analyzed population migration and travel data to offer a digital map of pandemic communities, a fever diagnosis, and even subway passenger traffic flow [51].

In response to the COVID-19 pandemic, many cities were on lockdown. People were unable to get together with family and friends, which inevitably led to social loneliness, isolation, and even difficulties of normal living, especially for seniors who live by them- 
selves or need the help of caregivers. Therefore, many people have chosen to adopt online digital platforms to participate in a certain amount of community network activity. For example, in Singapore, when Mothers' Day was held during lockdown, many citizens used e-commerce platforms to order flowers and gifts for their mothers [52,53]. Others used the Zoom video-conferencing platform to have virtual family gatherings [54].

Like many other communities around the world, thousands of Singaporeans across the country showed their support and appreciation for their healthcare and front-line workers with singing sessions [55]. Meanwhile, outside Singapore, more than 900 Singaporeans from all over the world were using digital technology to form a 'virtual collage choir', which was broadcasted on numerous digital platforms and was synchronized with the singalong session. A large number of community members also submitted their singalong video recordings, which were processed into a video collage and then posted online. It can be seen that digital platforms can be used to maintain social networks, despite social distancing limitations.

According to the above narratives, a greate variety of digital platforms were involved in engendering urban resilience during COVID-19. Social media platforms were used for disseminating information and knowledge, mobilizing human capital, maintaining social networks, and strengthening public participation in governance. E-commerce trading, service, and logistics platforms became the infrastructure to ensure some degree of normalcy of life and helping the economy and society to maintain vitality.

\subsection{The Negative Impact of Digital Platforms on Urban Resilience during COVID-19}

With the improvement of internet technology, exponential growth were seen in the use of digital platforms. As of June 2021, the total number of Chinese Internet users exceeded 1 billion [56]. The large number of Internet users provided a solid impetus for the development of China's digital industry. Such growth had also led to abuses, such as the indiscriminate collection of personal privacy information, and manipulative inducement of economic consumption (see Table 4).

Table 4. Digital platforms affects urban resilience negatively in COVID-19.

\begin{tabular}{|c|c|}
\hline Dimension & Examples \\
\hline Natural & Not found \\
\hline Infrastructure & Not found \\
\hline Institutional & Not found \\
\hline Economic & $\begin{array}{l}\text { The unhealthy "eating broadcast" phenomenon leads to food waste and spreads low taste values. } \\
\text { Some businesses force collection of personal information through e-commerce platforms. }\end{array}$ \\
\hline Social & $\begin{array}{l}\text { The teaching quality of online education has enormous uncertainties. } \\
\text { There is a "digital divide" among the elderly and other vulnerable people. } \\
\text { The private details of a woman in Chengdu were posted on the Internet. } \\
\text { Some businesses use big data analysis to conduct targeted marketing to consumers. }\end{array}$ \\
\hline
\end{tabular}

Muktang or Chibo in Chinese, is a form of online audiovisual broadcast centred on the consumption of food. This phenomenon started in South Korea and gradually swept across Asia and the world. But it gradually evolved into a homogenous curious behavior: the more they eat, the more they can attract traffic, bring attention, and benefit. Such unhealthy "eating broadcast" phenomenon subsequently led to damage to personal health, corruption of social morality, and even affected food security [57].

E-commerce platforms have also been found to have many problems, such as the in-discriminate collection of personal information and manipulative inducement of consumption. The social sharing function ignores the actual wishes of consumers. Some platforms allowed access to users' address book and location, including sharing such in-formation with other users in the vicinity, automatically adding others as friends, falsely 
sending friend applications, automatically sharing of online shopping records as well as browsing records, which is suspected of infringing on personal privacy. There are also behaviors such as inducing consumption, playing with word games, and false propaganda. The withdrawal activities on the platform will display misleading words such as "super easy mode", "only one friend's help", "only 0.01 yuan difference" and others, which are displayed every time. Due to the conditions of the activity, in fact, the success rate is very low, and the platform is suspected of false propaganda and misleading consumption [58].

The teaching quality of online education also presented vast uncertainties. On the one hand, there were varying pedagogical abilities among online teachers; on the other hand, students with weak self-management and poor learning abilities were also unsuitable for online teaching [59].

There is a "digital divide" among the elderly and the disabled, who have low participation in digitalization and are often denied taxi rides because they do not have a QR code and cannot enter or leave various places without a health code [60], e.g., several elderly people in Zhenjiang, Jiangsu province, were unable to get on the bus because they could not display the required "health code" on their old mobile devices.

A 20-year-old woman in Chengdu, China, was tested positive for nucleic acid. The personal particulars of the woman, such as her name, address, and other private information were subsequently posted on the Internet, and she was thus subjected to severe abuses online [61].

The application of facial recognition technology gradually expanded from a few security applications to many scenes in daily life. The advent of the pandemic accelerated this process. However, unscrupulous businesses used out facial recognition on consumers without their knowledge used the data to conduct targeted marketing to these consumers [62].

As the examples above showed, digital platforms can be a double-edged sword. Good use can promote the development of urban resilience, but otherwise, they canm also produce serious negative effects and thus weaken the resilience of cities.

\section{Conclusions}

\subsection{Main Implications}

As urbanization continues to accelerate, cities face increasing environmental, social, and economic challenges, requiring greater resilience to prevent and respond to challenges effectively. The digital platform is a research area that has attracted much attention recently. Digital platforms such as social media platforms, e-commerce platforms, and innovation platforms have become the core driving force for economic and social development. However, there is not much study on how digital platforms make cities more resilient. Based on this, this paper aimed to answer some questions about the main dimensions of urban resilience, how digital platforms enhance urban resilience, and how digital platforms contribute to urban resilience during COVID-19.

Firstly, an analysis of the relevant literature in the past decade found that urban resilience studies spanned across fields such as individual psychology, group behavior, community organization behavior, urban planning, regional development, disaster prevention and mitigation, sociology, philosophy, and other major disciplines. Through analyzing the urban resilience literature, five factors were identified to undergird urban resilience. The existing urban resilience conceptualization by different scholars, while different, was found to have some overlapping core fundamentals, which were how the five factors were derived. These five factors are (1) natural, (2) infrastructure, (3) institutional, (4) economic, and (5) social.

Secondly, the literature analysis on digital platforms shows that different digital platforms could enhance urban resilience from five dimensions: natural, infrastructure, institutional, economic, and social.

Further, considering the global COVID-19 pandemic in 2020, illustrative examples were drawn from Singapore and China to showcase how digital platforms can engender the development of urban resilience. The narratives on how China and Singapore used 
digital platforms in respond to the pandemic revealed that social media platforms played an important role in information sharing, strengthening social networks, and promoting public participation. At the same time, e-commerce transaction service platforms also made significant contributions to the ordinary operation of society during this period.

Finally, the study also showed that the widespread use of digital platforms may also lead to various abuses which seriously hinder the development of urban resilience.

Although this study indicates digital platforms could enhance urban resilience, further research will still be required. The specific mechanism of how various types of digital platforms enhance urban resilience under different event backgrounds has yet to be systematically and clearly understood. Moreover, as digital platforms are still rapidly developing and evolving, future research could also uncover new forms of digital platforms that best support the development of urban resilience.

\subsection{Limitations and Future Research}

This study has some limitations. First, Web of Science (WoS) databases were used to identify the literature on urban resilience, beginning in 2012 and ending in 2021. These data excluded non-academic papers such as book reviews, conferences, newspapers, and many early kinds of literature that were not included, so it may not be comprehensive enough. Second, as the literature mainly focused on English language publications, they may have an Anglo-American bias [63]. Moreover, the narratives only focused on China and Singapore, so they may not be sufficiently representatives.

Future research may look into these possible directions:

1. While the positive effect of digital platforms in enhancing urban resilience can be alluded, if the use of digital platforms is not strictly supervised, the digital platform may also lead to abuses, which is not conducive to the development of urban resilience and may even have negative effects on urban resilience (e.g., Table 4). Therefore, in the future, more attention needs to be paid to how to use digital platforms to enhance urban resilience while also ensuring that digital platforms are not abused. In addition, although the rise of digital platforms brought new opportunities to social and economic development, it has also caused an enormous impact on traditional industries (e.g., brick-and-mortar retail) [64]. Therefore, effectively combining traditional industries with digitalization while minimizing the modernization cost of traditional retail will also be an important direction of future research.

2. There are significant differences in the environment and man-made or natural disasters encountered in different countries and cities. Therefore, it may have practical significance to study the changes in urban resilience over a period of time for a single city.

3. Previous studies have focused on the resilience of cities to cope with natural disaster risks, such as floods, earthquakes and tsunamis, and infrastructure construction. In contrast, resilient studies on social, economic, and institutional dimensions are relatively lacking. This study found that digital platforms could be used to enhance urban resilience at the social, economic, and institutional levels. Therefore, future research on the social, economic, and institutional aspects of urban resilience should be strengthened, and the exploitation and application of digital platforms at the natural and infrastructure levels should be explored.

This study showed that digital platforms can enhance urban resilience. Further research will be needed to provide policymakers with clear and comprehensive understanding on how to develop urban resilience through the use of digital platform, while also limit the abuses and pitfalls that digital platforms may create for urban resilience.

Author Contributions: D.Q. contributed to the conception of the study and wrote the manuscript; B.L. performed the literature analyses and revise the manuscript; C.M.L.C. provided information on Singapore and edited portion of the manuscript. All authors have read and agreed to the published version of the manuscript. 
Funding: Innovative Methods Project of the Ministry of Science and Technology of the People's Republic of China (Project No. 2020IM010200, 2017IM010200).

Institutional Review Board Statement: Not applicable.

Informed Consent Statement: Not applicable.

Data Availability Statement: Not applicable.

Conflicts of Interest: The authors declare no conflict of interest.

\section{Appendix A. Dimensions of Urban Resilience}

Table A1. The numbers in parentheses in the Source column of Table A1 represent the year of publication and the number of co-citations in Google Scholar.

\begin{tabular}{|c|c|c|}
\hline Dimensions & Subdimensions & Source \\
\hline Natural & $\begin{array}{l}\text { Ecosystems, } \\
\text { Environment, } \\
\text { Biodiversity, } \\
\text { Hydrogeololgy. }\end{array}$ & $\begin{array}{l}\text { Tyler, \& Moench (2012, 630cited), Jabareen (2013, 622cited), Spaans, \& } \\
\text { Waterhout (2017, 200cited), Brown et al. (2012, 178cited), Collier et al. } \\
\text { (2013, 220cited), Allan et al. (2013, } 107 \text { cited), Ribeiro et al. (2019, } \\
\text { 105cited), Sharifi, \& Yamagata (2014, 102cited), Suárez et al. (2016, } \\
\text { 100cited), Olazabal \&Pascual (2016, 81cited), Tyler et al. (2016, } \\
\text { 57cited), Lorenz, \& Lal (2015, 56cited), Dhar, \& Khirfan (2017, } \\
\text { 56cited), Carvalho et al. (2017, 49cited), Klein et al. (2017, 25cited), } \\
\text { Rafael et al. (2017, 22cited), and Torabi et al. (2021, 6cited) }\end{array}$ \\
\hline Infrastructure & $\begin{array}{l}\text { Physical Infrastructure, Social } \\
\text { Infrastructure, Land Use and Structural } \\
\text { Design, Physical Capital, Transportation } \\
\text { network, Commercial and manufacturing } \\
\text { establishments, Water and Energy supply } \\
\text { systems, Flexibility of grid. }\end{array}$ & $\begin{array}{l}\text { Meerow (2016, 1403cited), Jabareen (2013, 622cited), Liao (2012, } \\
\text { 407cited), Desouza, \& Flanery (2013, 395cited), Collier et al. (2013, } \\
\text { 220cited), Spaans, \& Waterhout (2017, 200cited), Ribeiro et al. (2019, } \\
\text { 105cited), Sharifi, \& Yamagata (2014, 102cited), Tyler et al. (2016, } \\
\text { 57cited), Dhar, \& Khirfan (2017, 56cited), Klein, Koenig, \& Schmitt } \\
\text { (2017, 25cited), Rafael et al. (2017, 22cited), and Torabi et al. (2021, } \\
\text { 6cited). }\end{array}$ \\
\hline Institutional & $\begin{array}{l}\text { Governance, } \\
\text { Organized Governmental Services, } \\
\text { Resource Management, Warning and } \\
\text { Evacuation, Emergency Response, } \\
\text { Disaster Recovery, } \\
\text { Management Capacity. }\end{array}$ & $\begin{array}{l}\text { Meerow, (2016, 1403cited), Tyler, \& Moench (2012, 630cited), Jabareen } \\
\text { (2013, 622cited), Weichselgartner, \& Kelman (2014b, } \\
\text { 479cited),Desouza, \& Flanery (2013, 395cited), Vale(2014, 380cited), } \\
\text { McPhearson et al. (2015, 302cited), Chelleri et al. (2015, 287cited), } \\
\text { Wamsler et al. (2013, 276cited), Collier et al. (2013, 220cited), Lu, \& } \\
\text { Stead(2013, 208cited), Ziervogel et al. (2012, 205cited), Spaans, \& } \\
\text { Waterhout (2017, 200cited), Agudelo-Vera et al. (2012, 186cited), } \\
\text { Brown et al. (2012, 178cited), Friend, \& Moench (2013, 157cited), } \\
\text { Lhomme et al. (2013, 124cited), Coaffee (2013, 121cited), Ribeiro et al. } \\
\text { (2019, 105cited), Sharifi, \& Yamagata (2014, 102cited), Zaidi, \& Pelling } \\
\text { (2013, 88cited), Leitner et al. (2018, 78cited), Romero-Lankao, \& Gnatz } \\
\text { (2013, 68cited), Tyler et al. (2016, 57cited), Dhar, \& Khirfan (2017, } \\
\text { 56cited), Toubin et al. (2015, 45cited), Klein et al. (2017, 25cited), } \\
\text { Vivonid et al. (2017, 2cited), and Torabi et al. (2021, 6cited) }\end{array}$ \\
\hline Economic & $\begin{array}{l}\text { Society and Economy; } \\
\text { Employment; } \\
\text { Financial stability and flexibility; } \\
\text { Job diversity of residents; } \\
\text { housing capital; } \\
\text { E-commerce. }\end{array}$ & $\begin{array}{l}\text { Jabareen }(2013,622 \text { cited), Desouza, \& Flanery (2013, 395cited), Collier } \\
\text { et al. (2013, 220cited), Spaans, \& Waterhout (2017, 200cited), Brown } \\
\text { et al. (2012, 178cited), Mehmood (2016, 146cited), Ribeiro et al. (2019, } \\
\text { 105cited), Sharifi, \& Yamagata (2014, 102cited), Suárez et al. (2016, } \\
\text { 100cited), Tyler et al. (2016, 57cited), ARUP (2014, 28cited), Toubin } \\
\text { et al. (2015, 45cited). Klein et al. (2017, 25cited), and Torabi et al. } \\
\text { (2021,6cited). }\end{array}$ \\
\hline
\end{tabular}


Table A1. Cont.

\begin{tabular}{|c|c|c|}
\hline Dimensions & Subdimensions & Source \\
\hline Social & $\begin{array}{l}\text { Human Capital, Lifestyle and } \\
\text { Community Competence, Community } \\
\text { Capital, Social and Cultural Capital, } \\
\text { Population and Demographics, } \\
\text { Social values-cohesion, Social Networks, } \\
\text { Learning Capacity, Innovation, } \\
\text { Education, Cultural diversity, Faith-based } \\
\text { organizations. }\end{array}$ & $\begin{array}{l}\text { Tyler, \& Moench (2012,630cited), Jabareen (2013,622cited), Desouza, } \\
\text { \&Flanery (2013,395cited), McPhearson et al. (2015,302cited), Chelleri } \\
\text { et al. (2015,287cited), Collier et al. (2013,220cited), Lu, \& Stead } \\
\text { (2013,208cited), Ziervogel et al. (2012,205cited), Spaans, \&Waterhout } \\
\text { (2017,200cited), Agudelo-Vera et al. (2012,186cited), Brown et al. } \\
\text { (2012,178cited), Friend, \&Moench (2013,157cited), Pickett et al. } \\
\text { (2014,153cited), Mehmood (2016,146cited), Ribeiro et al. } \\
\text { (2019,105cited), Sharifi, \&Yamagata (2014, 102cited), Tyler et al. } \\
\text { (2016,57cited), Dhar, \& Khirfan (2017,56cited), Toubin et al. } \\
\text { (2015,45cited), ARUP (2014,28cited), Boix et al. (2017,25cited), Klein } \\
\text { et al. (2017,25cited), Rafael et al. (2017,22cited), and Torabi et al. } \\
\text { (2021,6cited) }\end{array}$ \\
\hline
\end{tabular}

\section{References}

1. Maclean, K.; Cuthill, M.; Ross, H. Six Attributes of Social Resilience. J. Environ. Plan. Manag. 2014, 57, 144-156. [CrossRef]

2. Alexander, D.E. Resilience and disaster risk reduction: An etymological journey. Nat. Hazards Earth Syst. Sci. 2013, 13, 2707-2716. [CrossRef]

3. Holling, C.S. Resilience and Stability of Ecological Systems. Ann. Rev. Ecol. Syst. 1973, 4, 1-23. [CrossRef]

4. $\quad$ Meerow, S.; Newell, J.P.; Stults, M. Defining urban resilience: A review. Lands. Urban Plan. 2016, 147, 38-49. [CrossRef]

5. ARUP. City Resilience Framework; ARUP: London, UK, 2014.

6. Spaans, M.; Waterhout, B. Building up resilience in cities worldwide-Rotterdam as participant in the 100 Resilient Cities Programme. Cities 2017, 61, 109-116. [CrossRef]

7. Ribeiro, P.J.G.; Gonçalves, L.A.P.J. Urban resilience: A conceptual framework. Sustain. Cities Soc. 2019, 50, 101625. [CrossRef]

8. Torabi, E.; Dedekorkut-Howes, A.; Howes, M. A framework for using the concept of urban resilience in responding to climaterelated disasters. Urban Res. Pract. 2021, 1-23. [CrossRef]

9. McMillen, H.; Campbell, L.K.; Svendsen, E.S.; Reynolds, R. Recognizing stewardship practices as indicators of social resilience: In living memorials and in a community garden. Sustainability 2016, 8, 775. [CrossRef]

10. Tilson, D.; Sorensen, C.; Lyytinen, K. Change and Control Paradoxes in Mobile Infrastructure Innovation: The Android and iOS Mobile Operating Systems Cases. In Proceedings of the 45th Hawaii International Conference on System Sciences, Maui, HI, USA, 4-7 January 2012; pp. 1324-1333. [CrossRef]

11. Darking, M.; Whitley, E.A.; Dini, P. Governing diversity in the digital ecosystem. Commun. ACM 2008, 51, 137-140. [CrossRef]

12. Spagnoletti, P.; Resca, A.; Lee, G. A Design Theory for Digital Platforms Supporting Online Communities: A Multiple Case Study. J. Inf. Technol. 2015, 30, 364-380. [CrossRef]

13. Jacobides, M.G.; Cennamo, C.; Gawer, A. Towards a Theory of Ecosystems. Strateg. Manag. J. 2018, 39, 2255-2276. [CrossRef]

14. Tiwana, A. Research Commentary -Platform Evolution: Coevolution of Platform Architecture, Governance, and Environmental Dynamics. Inf. Syst. Res. ISR Inf. Syst. J. Inst. Oper. Res. Manag. Sci. 2010, 21, 675-687. [CrossRef]

15. Wareham, J.; Fox, P.B.; Cano Giner, J.L. Technology Ecosystem Governance. Organ. Sci. 2014, 25, 1195-1215. [CrossRef]

16. de Reuver, M.; Sørensen, C.; Basole, R.C. The Digital Platform: A Research Agenda. J. Inf. Technol. 2018, 33, 124-135. [CrossRef]

17. Tilson, D.; Lyytinen, K.; Sørensen, C. Digital Infrastructures: The Missing IS Research Agenda. Inf. Syst. Res. 2010, 21, 748-759. [CrossRef]

18. Alaimo, C.; Kallinikos, J.; Valderrama, E. Platforms as service ecosystems: Lessons from social media. J. Inf. Technol. 2020, 35, 25-48. [CrossRef]

19. Adner, R.; Kapoor, R. Value creation in innovation ecosystems: How the structure of technological interdependence affects firm performance in new technology generations. Strateg. Manag. J. 2010, 31, 306-333. [CrossRef]

20. Parker, G.; Van Alstyne, M. Innovation, Openness, and Platform Control. Manag. Sci. 2017, 64, 3015-3032. [CrossRef]

21. Chen, Y.; Chen, C.; Wang, Z.Y. The methodology function of CiteSpace mapping knowledge domains. Stud. Sci. Sci. 2015, 33, 242-253. [CrossRef]

22. Chen, C.; Hu, Z.; Liu, S.; Tseng, H. Emerging trends in regenerative medicine a scientometric analysis in CiteSpace. Expert Opin. Biol. Ther. 2012, 12, 593-608. [CrossRef]

23. Chen, C.; Ibekwe-SanJuan, F.; Hou, J. The structure and dynamics of cocitation clusters: A multiple-perspective cocitation analysis. J. Am. Soc. Inf. Sci. Technol. 2010, 61, 1386-1409. [CrossRef]

24. Nitoslawski, S.A.; Galle, N.J.; Van Den Bosch, C.K.; Steenberg, J.W.N. Smarter ecosystems for smarter cities? A review of trends, technologies, and turning points for smart urban forestry. Sustain. Cities Soc. 2019, 51, 101770. [CrossRef]

25. Bhaskara, S.; Bawa, K.S. Societal Digital Platforms for Sustainability: Agriculture. Sustainability 2021, 13, 5048. [CrossRef]

26. Dwivedi, A.K. Role of digital technology in freshwater biodiversity monitoring through citizen science during COVID-19 pandemic. River Res. Appl. 2021, 37, 1025-1031. [CrossRef] [PubMed] 
27. Farinosi, M.; Trere, E. Social Movements, Social Media and Postdisaster Resilience. Available online: www.publishing.monash. edu/books/tpecsi-9781921867620.html (accessed on 12 January 2022).

28. Effendi, S.Y.T. The Utilization of Digital Social Media in Disseminating the Issue of Multicultural Education to Strengthen the Social Resilience among Adolescents. KNE Soc. Sci. 2019, 379-394. [CrossRef]

29. Udwan, G.; Leurs, K.; Alencar, A. Digital resilience tactics of Syrian refugees in the Netherlands: Social media for social support, health, and identity. Soc. Media Soc. 2020, 6. [CrossRef]

30. Reuter, C.; Spielhofer, T. Towards social resilience: A quantitative and qualitative survey on citizens' perception of social media in emergencies in Europe. Technol. Forecast. Soc. Change 2017, 121, 168-180. [CrossRef]

31. Young, J.C. Rural digital geographies and new landscapes of social resilience. J. Rural Stud. 2019, 70, 66-74. [CrossRef]

32. Shurong Zheng, X.W. Research on the Development of Shanghai Tourism Industry under the Sharing Economy Mode. Mod. Manag. 2019, 9, 24-30. [CrossRef]

33. SASC. Global Digital Economy Competitiveness Development Report. 2019. Available online: https://www.pishu.com.cn/ skwx_ps/bookdetail?ID=11375263\&SiteID=14 (accessed on 12 January 2022).

34. Heng, M. Malls, Shops Gear Up to Ensure Safety Measures and Crowd Control. Available online: https://www.straitstimes. $\mathrm{com} /$ singapore/coronavirus-malls-and-stores-gear-up-to-manage-crowds-on-friday-when-phase-2-re-opening (accessed on 12 January 2022).

35. Baharudin, H. Coronavirus: Contact Tracing App Update Fixes Battery Drain in IPhones. Available online: https://www. straitstimes.com/singapore/contact-tracing-app-update-fixes-battery-drain-in-iphones (accessed on 12 January 2022).

36. Yip, W.Y. Coronavirus: 10,000 Seniors Get First Batch of TraceTogether Tokens. Available online: https:/ / www.straitstimes.com/ singapore/10000-seniors-get-first-batch-of-tracetogether-tokens (accessed on 12 January 2022).

37. $\mathrm{Ng}$, H.S. Senior-Centric Activities by Government Agencies to be Suspended as Part of Additional COVID-19 Measures: MOH. Available online: https:/ / www.channelnewsasia.com/singapore/coronavirus-covid19-senior-activities-suspended-moh-safrajurong-770816 (accessed on 12 January 2022).

38. Guanghua, H. About 40,000 Builders Built Huoshenshan and Leishenshan Hospitals in About 10 Days. Available online: http:/ / www.xinhuanet.com/2020-04/21/c_1125882638.htm (accessed on 12 January 2022).

39. Lim, M.Z. Focus on Celebrating at Home, Many Segments Moved to the Heartlands and Smaller-Scale Evening Show. Available online: https://www.straitstimes.com/singapore/ndp-2020-focus-on-celebrating-at-home-many-segments-movedto-the-heartlands-and-smaller\#: \{\}:text=Podcasts-,NDP\%202020\%3A\%20Focus $\% 20$ on $\% 20$ celebrating $\% 20$ at $\% 20$ home $\% 2$ C $\% 20$ many\%20segments\%20moved, and\%20smaller\%2Dscale\%20evening\%20show\&text=SINGAPORE\%20\%2D\%20This\%20year \ T1 \textquoterights\%20National\%20Day,floating\%20platform\%20at\%20Marina\%20Bay (accessed on 12 January 2022).

40. People's Daily: Governments at All Levels Must Put Themselves in Consideration of the Difficulties of Enterprises. Available online: https:/ / news.sina.com.cn/c/2020-02-24/doc-iimxyqvz5335542.shtml (accessed on 12 January 2022).

41. Zhang, D.D.J.J. Pandemic in a smart city Singapore's COVID-19 management through technology \& society. Urban Geogr. 2020, 42, 408-416. [CrossRef]

42. Wang, W.; Wu, Z. Research on Digital Economic Development under the Influence of COVID-19. Econ. Vert. Horizon. 2020, 3. [CrossRef]

43. SGAssist. Available online: https:/ /www.sgassist.com/ (accessed on 12 January 2022).

44. Basu, M. Singapore's Seniors Pick Up Smartphones to Cope with COVID-19. Available online: https://govinsider.asia/digitalgov/five-ways-singapore-builds-disability-inclusive-services/ (accessed on 12 January 2022).

45. Jones, L. Coronavirus: What's Behind the Great Toilet Roll Grab? Available online: https://www.bbc.com/news/business-5204 0532 (accessed on 12 January 2022).

46. Prior, R. Why Are We Hoarding Toilet Paper? It May Be Your Personality Type. Available online: https://www.wfsb.com/whyare-we-hoarding-toilet-paper-it-may-be-your-personality-type/image_932e6617-2a98-5550-aa1e-f7e9745fcd5f.html (accessed on 12 January 2022).

47. Leong, D. Commentary: Telegram, the Powerful COVID-19 Choice of Communications by Many Governments. Available online: https:/ / www.channelnewsasia.com/commentary/coronavirus-covid-19-government-telegram-whatsapp-fake-newsinfo-936061 (accessed on 12 January 2022).

48. Fisher, D. Why Singapore's Coronavirus Response Worked-And What We Can All Learn. Available online: https://www.scmp. com/week-asia/opinion/article/3076885/why-singapores-coronavirus-response-worked-and-what-we-can-all (accessed on 12 January 2022).

49. Qing, X. Give Full Play to the Role of Digitalization in the Fight against the Epidemic. Available online: http://zj.people.com.cn/ n2/2020/0319/c186327-33887473.html (accessed on 12 January 2022).

50. Min, W. “An Old Man Was Blocked from Riding the Subway without a Health Code” Triggered Discussion. Available online: https:/ / www.sohu.com/a/412310257_661771 (accessed on 12 January 2022).

51. Muyu, W. Baidu Maps Migration Big Data Platform Shows Its Skills in Anti-epidemic Sniper War. Available online: https: //www.sohu.com/a/371065242_120061090 (accessed on 12 January 2022).

52. Wong, K. Families Celebrating Online This Mother's Day Due to Circuit Breaker Measures. Available online: https://www. channelnewsasia.com/watch/families-celebrating-online-mothers-day-due-circuit-breaker-measures-video-1471541 (accessed on 12 January 2022). 
53. Lim, J. Dutch Lilies and Kenyan Roses for Mother's Day. Available online: https://www.straitstimes.com/singapore/manpower/ dutch-lilies-and-kenyan-roses-for-mothers-day (accessed on 12 January 2022).

54. Stewart, M. No Visiting? No Problem: Why a Circuit Breaker Hari Raya Will Still Be Special. Available online: https: / cnalifestyle. channelnewsasia.com/entertainment/hari-raya-2020-circuit-breaker-singapore-194011 (accessed on 12 January 2022).

55. Heng, M. Coronavirus: Popular Song Home Sun across Singapore to Thank Front-Line, Migrant Workers. Available online: https: / / www.straitstimes.com/singapore/popular-song-home-sung-across-singapore-to-thank-front-line-migrant-workers (accessed on 12 January 2022).

56. CNNIC: The 48th Statistical Report on China's Internet Development in 2021. Available online: http:/ / www.199it.com/archives/ 1302411.html (accessed on 12 January 2022).

57. The hazards of the Big Stomach King's Eating and Broadcasting Are More Terrifying than CCTV's Criticism. Available online: https:/ / www.sohu.com/a/413248708_120509339 (accessed on 12 January 2022).

58. Jiangsu Released a Report: 7 e-Commerce Platforms Suspected of Infringing on Consumer Rights. Available online: http: //jiangsu.china.com.cn/html/jsnews/society/10896521_1.html (accessed on 12 January 2022).

59. Online Teaching Puzzles and Choices. Available online: https:// caijing.chinadaily.com.cn/a/202005/27/WS5ecdec67a31057c5 cbc2ea36.html (accessed on 12 January 2022).

60. Elderly People without a Health Code Are Blocked from Taking the Subway. Available online: https://baijiahao.baidu.com/s? id=1675506383089382261\&wfr=spider\&for=pc (accessed on 12 January 2022).

61. A 20-Year-Old Woman in Chengdu Was "Internet Violence" in Many Bars before the Diagnosis! Full Exposure of Personal Information. Available online: https://baijiahao.baidu.com/s?id=1685481146017806062\&wfr=spider\&for=pc (accessed on 12 January 2022).

62. The Sales Office Abuses the Face Recognition Black Box Operation, Pay Attention to Buying a House. Available online: https:/ / www.sohu.com/a/500709684_120295675 (accessed on 12 January 2022).

63. Joshua, P.; Newell, J.P.N. The Boundaries of Urban Metabolism: Towards a Political-Industrial Ecology. Prog. Hum. Geogr. 2014, 39, 702-728. [CrossRef]

64. Findlay, A.; Sparks, L. Far from the 'Magic of the Mall': Retail (Change) in 'Other Places'. Scott. Geogr. J. $2012,128,24-41$. [CrossRef] 